\title{
Analysis Of Rice Consumer Loyalty In Pekanbaru City
}

\author{
Chezy WM Vermila ${ }^{1}$, Andi Alatas ${ }^{2}$ \\ Lecturer at the Agribusiness Study Program, Faculty of Agriculture, \\ Kuantan Singingi Islamic University \\ ${ }^{*}$ Corresponding author: \\ Email: chezywmvermila16@gmail.com
}

\begin{abstract}
.
This study aims to determine the loyalty of consumers who buy rice in Pekanbaru City. The method used is the survey method for households in Pekanbaru City, which consists of 12 Districts which are divided proportionally based on BPS data in 2020. The sample in this study is 240 households, based on the field survey results obtained for consumer characteristics are at $84.00 \%$ of the productive age ranges from 15 - 35 years old. For educational characteristics, $63.41 \%$ of undergraduate consumer education (S1) covers various fields of science. Then for the characteristics of income, it is found that as much as $6.92 \%$ of consumer income is 2,888,564 or equivalent to MSEs. Whereas for the type of work obtained as many as $57.4 \%$ have a livelihood / job as private employees. Meanwhile, the results of the analysis of consumer loyalty are not yet at the level of loyal buyers because the loyalty pyramid value of Switcher buyers is still above $50 \%$ and the value of committed buyers is still very small, namely $26.67 \%$. The level of loyalty of rice consumers in the city of Pekanbaru is not yet at the level of loyal buyers because in the loyalty pyramid the value of Switcher buyers is still above 63\%, which is $56.61 \%$ with the frequent category and the committed buyer value is also very small, namely $49.72 \%$ with the non-category. like, for the value of Liking The Brand and Satisfied Buyer, which is $100 \%$ with the very satisfied category. And the Habitual Buyer value is $96.66 \%$ with the category agree.
\end{abstract}

Keywords: loyalty, rice, consumers

\section{INTRODUCTION}

Consumer behavior as part of human activities that always changes according to the environmental and social influences where he is. However, the expected consumer behavior for the company is loyalty. Loyalty means customers continue to make purchases on a regular basis. Customer loyalty in general can be defined as one's loyalty to a product, both certain goods and services. There are several definitions of loyalty according to experts, including the following: Loyalty according to Griffin (2002: 4), (In Hurriyati, 2010, p. 128) states that "loyalty is defined as non random purchase expression dover time by somedecision making unit ". Based on this definition, it can be seen that loyalty is more indicated by a behavior, which is indicated by routine purchases, based on the decision-making unit.Customer loyalty has an important role in a company, maintaining them means improving financial performance and maintaining the viability of the company, this is the main reason for a company to attract and retain them. According to Berry in Tjiptono (2005), (In Rofiq, 2009), customer loyalty can be defined as a response that is closely related to a pledge or promise to uphold the commitment that underlies the sustainability of the relationship, and is usually reflected in consistent repeat purchases.A consumer can become a loyal customer because of several factors that determine loyalty to a product or service. In building and increasing customer loyalty, companies must pay attention to the factors that influence it. According to Robinette (2001: 13) the factors that influence customer loyalty are caring, trust, protection (length of patronage), and accumulative satisfaction (overallsatisfaction).

Rice is the result of processing from an agricultural product called rice (Oryza sativa). Rice is a food commodity that is used as a staple food for Asian nations, especially Indonesia, Thailand, Malaysia, Vietnam, Japan and Myanmar. Rice seeds consist of two parts, namely the edible part (rice caryopsis) and the skin (hull or husk) (Ambarinanti, 2007).The general definition of rice is in accordance with the 
Regulation of the Minister of Trade of the Republic of Indonesia Number 19 / M-DAG / PER / 3/2014, which explains that rice is a grain either skinned, without skin, processed or unprocessed from Oriza Sativa. milled rice, and cracked rice. While the general definition, rice is part of the grain of rice (unhulled) which has been separated from the husk and bran or bran (Ministry of Agriculture, 2015). This definition denotes rice as the final product of grain.One of the marketing strategies that can be applied in winning the market competition in this industry is a brand development strategy. In the beginning, the brand only played a role in differentiating the products offered by a manufacturer from other similar products so that consumers could more easily identify the product they wanted to buy. However, in fact the role of the brand is not limited only to what differentiates it from other products, but a brand can be pursued more so that it has a strong brand equity or has the potential to be a competitive advantage.In this study, the authors examined how consumer loyalty in purchasing rice products by measuring Switcher Buyer, Habitual Buyer, Satisfied Buyer, Liking the Brand and Commited Buyer.

\section{METHOD}

This research was conducted in Pekanbaru City using 12 existing Districts. The number of samples taken was 240 households which were divided proportionally. The sampling technique used in this study was purposive sampling method (purposive sampling technique). Puposive sampling is one of the non-random sampling techniques where the researcher determines the sampling by determining special characteristics that are in accordance with the research objectives so that it is expected to be able to answer research problems. The type of data collected in this study comes from primary data and secondary data. Primary data is data that is collected directly by researchers through the source by conducting research on the object under study including consumer characteristics such as age, education, income, family dependents, occupation.Secondary data is data that does not directly provide data to researchers. This secondary data is obtained from related agencies, such as the Central Bureau of Statistics, using literature studies conducted on many books, and obtained from the internet related to research.The analysis used in this research is the analysis of consumer loyalty with the measurement of Swicher buyers, committed buyers, liking brands, and satified buyers.

\section{RESULTS AND DISCUSSION}

Consumer characteristics raised in this study are characteristics related to rice. The observed consumer characteristics are: a. Age is an important factor in influencing rice decisions. Based on the survey in the field, it is known that the largest consumers purchase rice, namely $1 \%$ vulnerable age $0-14$ years, 15 35 years old as much as $84 \%$, aged $>36$ as much as $15 \%$. b.the characteristics of the education category, as for the level of consumer education, namely strata 1 as much as $63.41 \%$, for completing high school as much as $17.05 \%$, junior high school education equivalent to 10.27 , for basic education as much as 3.56 and for not going to school as much as 5,71\%. Analysis of consumer loyalty. This analysis is used to measure the level of consumer loyalty in using / buying bakery products at Rotte Bakery stores. According to Durianto et al. (2004) the analysis used in measuring the level of loyalty is the analysis of Switcher Buyers, Habitual Buyers, Satisfied Buyers, Liking the Brand.

1.Analysis Switcher Buyer Switcher is a consumer who is sensitive to price changes, so that the level of loyalty is placed at the bottom of the order. Respondents who fall into this category are respondents who answered "often" and "very often" in answering the question "what will the respondent be if the price goes up?

Table 6.Calculation Analysis of Switcher Buyer Rice consumers

\begin{tabular}{|l|l|l|l|l|l|}
\hline \multicolumn{9}{|c|}{ Switcher Buyer } \\
\hline Product & Answer & \multicolumn{1}{|c|}{ x } & f & x.f & \% \\
& & 1 & 73 & 10 & 30,41 \\
\hline $\begin{array}{l}\text { Rice: anak daro, kuruik } \\
\text { kusuik, fragrant }\end{array}$ & Never & 2 & 17 & 20 & 7,08 \\
\cline { 2 - 7 } & Often & 20 &
\end{tabular}




\begin{tabular}{|l|l|l|l|l|l|}
\hline pandanus, chef's ha & Very often & 3 & 150 & 30 & 62,5 \\
\hline Total & & 240 & 60 & 100 \\
\hline Average & $240 / 60=4$ \\
\hline Swicher buyer & $(10+10) / 240 * 100 \%=66,66$ \\
\hline
\end{tabular}

Processed data, 2021

Based on the data above, it is recognized that consumers will move from one brand to another due to price changes. This is indicated by the average value of 4 which is categorized frequently in the range $1.68-$ 2.35. The consumers who are really sensitive to the price of rice are 150 respondents or $62.5 \%$.

2. Habitual buyer analysis, categorized as consumers who are satisfied with the brand of the product that is consumed or at least consumers do not experience dissatisfaction in consuming the product brand (Durianto et al, 2001).

Table 7. Calculation of Habitual Buyer of Rice Consumers in Pekanbaru City

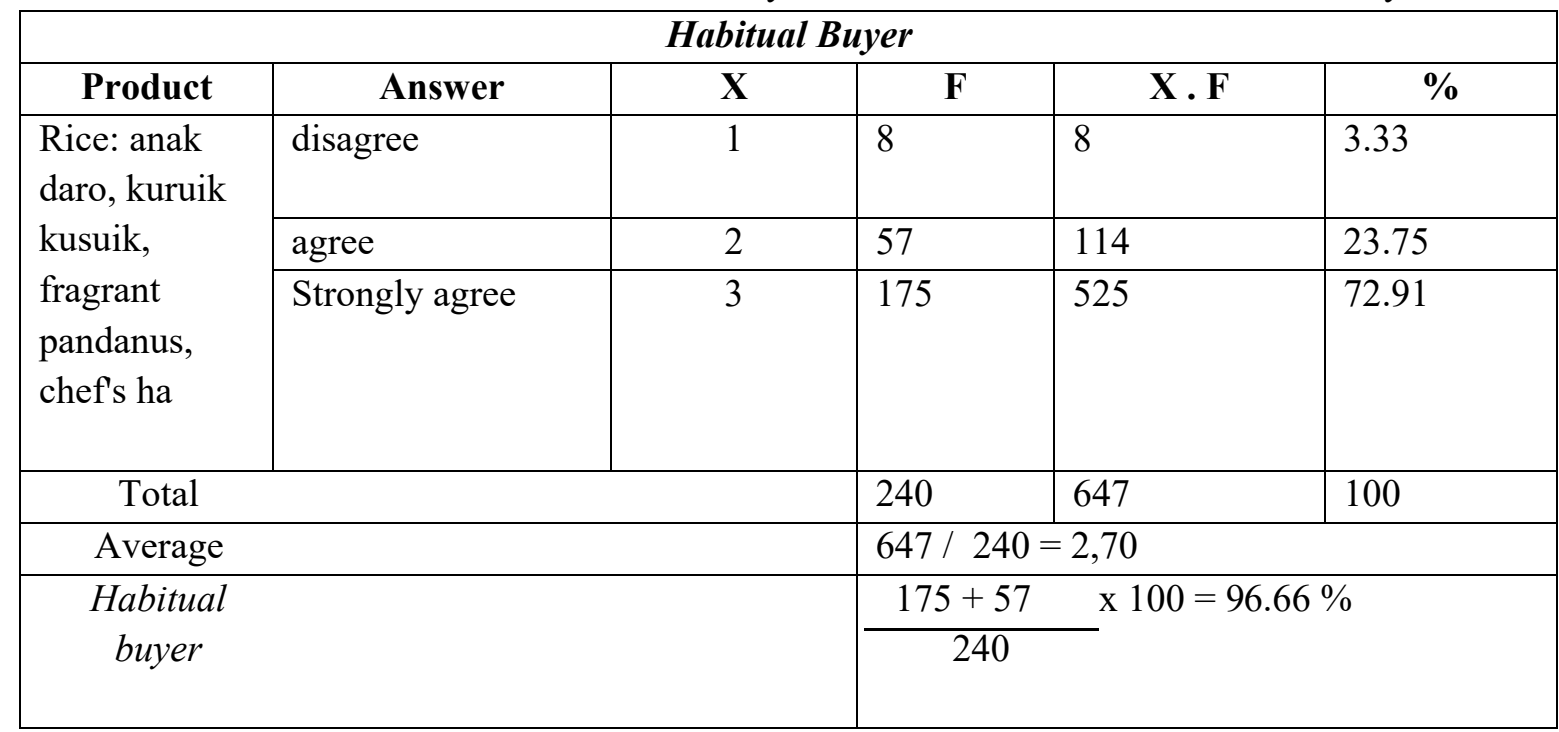

\section{Processed data, 2021}

Based on the processed data, the results show that "Rice" consumers strongly agree that packaged rice products are the choice due to habitual factors. This is indicated by an average value of 2.70 . And the confidence level is $96.66 \%$. This is because consumers feel satisfied and want to buy rice with the same brand again because the quality of the product produced from the rice chosen by consumers is the same even though consumers buy in different places.

3. Stisfied Buyer Analysis. Satisfied Buyer; measured through three questions: (a) Are consumers satisfied with the brands used, (b) Are consumers satisfied with the price of the brands used, (c) Are consumers satisfied with the services of the producers of the brands used. This stage will find various data related to the three question indicators that the researcher has asked the respondent through a questionnaire. The sum of the scores from the three question indicators, a cumulative score will be included which will be included in the low or high category based on the level of the continuum that has been made. high. Based on the results of these data findings, it can also be concluded that the findings of the research data are relevant to the theory of satisfied buyers, where satisfied buyers describe consumers who are satisfied with the brands consumed. Consumers in this stage have considerable consideration in choosing a brand, but at this level there is also the possibility of customers changing a brand if there is a risk regarding costs (Aaker, 1997).

Table 8. Analysis of Satisfied Buyers of rice consumers in Pekanbaru City.

\begin{tabular}{|l|l|c|l|l|l|}
\hline \multicolumn{1}{|c|}{ Satisfied Buyer } \\
\hline \multicolumn{1}{|c|}{ Produk } & \multicolumn{1}{|c|}{ Answer } & X & \multicolumn{1}{c|}{ F } & \multicolumn{1}{c|}{ X.F } & \multicolumn{1}{c|}{$\%$} \\
\hline $\begin{array}{l}\text { Rice: anak } \\
\text { daro, } \text { kuruik }\end{array}$ & Not satisfied & 1 & 15 & 15 & 2.98 \\
\cline { 2 - 6 } & Satisfied & 2 & 188 & 376 & 74.90 \\
\hline
\end{tabular}




\begin{tabular}{|c|l|l|l|l|l|}
\hline $\begin{array}{l}\text { kusuik, } \\
\text { fragrant } \\
\text { pandanus, } \\
\text { chef's ha }\end{array}$ & Very satisfied & 3 & 37 & 111 & 22.11 \\
\hline Total & & 240 & 502 & 100 \\
\hline Average & $502 / 240=2.1$ & \\
\hline $\begin{array}{l}\text { Satisfied } \\
\text { buyer }\end{array}$ & $\frac{188+37}{240} \times 100=93.75 \%$ \\
\hline
\end{tabular}

\section{Processed data, 2021}

4. Analysis of Liking the brand, namely another factor that can also affect consumer confidence in the brand is trus in the company. Trust in the company with regard to building trust in the company is required to have a good or positive corporate image. Corporate image is the perception of a company which is reflected in the associations contained in the consumer's memory (Keller, 1998).

In this stage, various data will be found related to the three question indicators that the researcher has asked the respondent through a questionnaire. The sum of the scores from the three question indicators, a cumulative score will be included which will be included in the low or high category based on the level of the continuum that has been made. As a result, the sub-variable liking the brand has a total score of 800 . From the continuum range that has been made by the researcher, it can be seen that the score is in the interval 751 to 1200 , which is the limit for the high category. This shows that the data found by researchers is relevant to the theory of liking the brand as stated by Aaker (in Durianto 2004) that liking the brand describes consumers who really like a particular brand. At this level, consumers begin to feel emotional with a brand. This feeling generally arises because of the experience and association in the use of the brand and other brands. Also mentioned by Aaker (1997), customer liking can be realized by the high quality impression of the brand. Besides that, the tendency of people nowadays is to trust the brands they are familiar with that are also known to many people.

Table 9. Liking the brand of rice consumers in Pekanbaru City.

\begin{tabular}{|c|c|c|c|c|c|}
\hline \multicolumn{6}{|c|}{ Liking the brand } \\
\hline Product & Answer & $\mathbf{X}$ & $\mathbf{F}$ & X.F & $\%$ \\
\hline \multirow{3}{*}{$\begin{array}{l}\text { Rice: anak daro, } \\
\text { kuruik kusuik, } \\
\text { fragrant } \\
\text { pandanus, chef's } \\
\text { ha }\end{array}$} & Do not like & 1 & 3 & 3 & 1.25 \\
\hline & Like & 2 & 16 & 32 & 6.66 \\
\hline & Really like & 3 & 221 & 663 & 92.08 \\
\hline \multicolumn{2}{|l|}{ Total } & & 240 & 698 & 100 \\
\hline \multicolumn{2}{|l|}{ Average } & & \multicolumn{3}{|c|}{$698 / 240=2.90$} \\
\hline \multirow{2}{*}{\multicolumn{2}{|c|}{ Satisfied buyer }} & & $16+$ & \multirow{2}{*}{\multicolumn{2}{|c|}{$\mathrm{x} 100=98.75 \%$}} \\
\hline & & & & & \\
\hline
\end{tabular}

Processed data, 2021

\section{CONCLUSION}

After analyzing the tendency of consumers to occupy the hierarchical position of the brand loyalty pyramid, it can be concluded that rice consumers in Pekanbaru City have a tendency to occupy the positions of Habitual Buyer, Satisfied Buyer and Liking The Brand in the brand loyalty pyramid hierarchy because the data findings show that consumers are at this level. high category in the continuum. The results of data analysis also show that respondents who dominate the tendency to occupy the level of buyer habitual, 
satisfied buyers and liking the brand are housewives.Based on the results of the research and the conclusions that have been taken, the suggestions for further research are that it is expected to use other elements of brand equity as research variables, including brand awareness, perceived quality, brand association, and assets. -Other proprietary brand assets.

\section{ACKNOWLEDGMENTS}

The author's thanks go to all those who have helped a lot, especially for the author's team, namely Mr. Andi Alatas as a partner in the research, then to consumers who have been willing to provide information about the object of research provided by the researcher.

\section{REFERENCE}

[1] Aaker, D., 1997. Brand Equity Management. Main Partner: Jakarta

[2] Dariyo, Agoes. 2004. Adolescent Developmental Psychology. Ghalia Indonesia: Jakarta

[3] Durianto, Darmadi. 2004.

[4] Strategies to Conquer the Market Through Brand Equity Research and Brand Behavior. PT. Gramedia Pustaka: Jakarta Durianto D., Sugiarto, Budiman L.J. 2004.

[5] Brand Equity Ten: Market Leading Strategy. PT. Gramedia Pustaka Utama: Jakarta

[6] Hanggadhika, Hardian. 2010. The Influence of Brand Equity on Consumer Purchase Decisions of Nokia Brand Mobile Products in Semarang. Undergraduate Theses: Airlangga University

[7] Hurlock, E.B. 1990. Developmental Psychology 5th Edition. Erlangga: Jakarta

[8] Hurlock, E.B. 2008. Developmental Psychology: A Lifetime Approach. Erlangga: Jakarta

[9] Hurriyati, Ratih. 2005. Marketing Mix and Consumer Loyalty. Publisher CV. Alfabeta: Bandung.

[10] Kotler, P and K.L. Keller. 2006.12th edition. Marketing Management. Prentice Hall, Inc .: New Jersey

[11] Mulyana, Deddy. 2004, An Introduction to Communication Studies. PT. Youth Rosdakarya: Bandung 